\title{
Sustainable Urban Development with Emphasis on Worn Out Texture Regeneration (Case Study: Isfahan, Iran)
}

\author{
Seyed Hamidreza Rozati ${ }^{1}$, Mahshad Kazemzadeh ${ }^{2}$, Amirmehdi Vaseghi ${ }^{3}$ \\ ${ }^{1}$ Department of Architecture \& Urban Planning, Shahid Rajaee Teacher Training University, Tehran, Iran \\ ${ }^{2}$ Department of Design, Texas Tech University, Lubbock, USA \\ ${ }^{3}$ Department of Architecture \& Urban Planning, Islamic Azad University of Najaf Abad, Isfahan, Iran \\ Email: Hamidrezarozati@yahoo.com, Mahshad.kazemzadeh@yahoo.com, Amirmehdi.vaseghi@gmail.com
}

Received 16 July 2015; accepted 7 September 2015; published 10 September 2015

Copyright (C) 2015 by authors and Scientific Research Publishing Inc.

This work is licensed under the Creative Commons Attribution International License (CC BY). http://creativecommons.org/licenses/by/4.0/

(c) (i) Open Access

\begin{abstract}
In recent years, due to the natural population growth and immigration, demand for houses in many of the large cities has risen. In spite of the fact that there are lots of lands which are abandoned or occupied with inappropriate uses as worn out texture in down towns, large cities have the problem of physical disintegration and unplanned development towards farming lands and suburb gardens which will result in huge unsustainability in different dimensions including economic, social, physical and environmental. Using the potentials of worn out textures in down towns is one of the solutions, which has been noted in literature of infill city developments in recent years in order to achieve a sustainable development. In this research, potentials of worn out texture of the city of Isfahan as a sustainable approach for future development have been investigated and some solutions have been suggested in order to have an optimal guidance which is based on regeneration of worn out textures. Methodology of the research is descriptive and analytic and is identically practical. The data have been gathered through librarian references, observation and questioners. After it, the area of worn out texture in down town was calculated and then through using clustering model, the number of houses needed in the city of Isfahan in the year 2025 was estimated. The results of the research indicate that in inner city context of Isfahan, due to the existence of the worn out textures, providing house is approachable and worn out texture regeneration can be considered as a sustainable approach for future urban development.
\end{abstract}

\section{Keywords}

Sustainable Development, Worn Out Texture, Regeneration, Infill City Development, Isfahan 


\section{Introduction}

These days, the growth in most cities of the developing countries specially in the cities of Iran has culminated in the vertical growth of the cities (Parizadi et al., 2012), whose sustainability has been neglected in most of the cases. In this kind of development, one of the most important sustainable-related challenges to be discussed is the disintegrations which are imposed on physical body and social structure of the city. Therefore, because of the given problems and great expenses which are forced on cities by this development, the need for a new approach in urban development based on a review of the existing potentials in cities is tangible more than ever. This kind of development which is known as infill city development is considered as a solution for preservation of cities' resources and improvement of their life cycle process specially, in cities that have some limitations in terms of horizontal development.

Most of the urban lands are either out of use or occupied with infrastructure facilities like prisons and garrisons or even those in which there is not any balance between the value of land and existing infrastructures and this has been culminated for cities to be developed just towards sub-urban (Lang et al., 2000). While infill development can be encouraged in order to preserve the environment and ruination of the farming lands outside of the cities. Therefore, sustainable development can be achieved in an infill physical development (Cole et al. 1996). One of the main differences between infill development in Iran and other developing countries is related to the previous utilizations. Most of the cities in Iran are ancient ones that have historical fabrics as well. Lack of management in matrix planning of these sites can result in their physical and social dilapidation which can make the lands abandoned or with improper utilities in down town. Therefore, in most of the historical cities of Iran, the practical infill development regions are located in the worn out textures with focus on enhancing their good potential as housing lands whereas, in developed countries, most of the abandoned lands belong to industrial utilities which bring with them environmental dangers as well (Parizadi et al., 2012).

Isfahan is one of the historical cities, which has experienced an enormous growth in the number of emigrants. Today's developments of Isfahan have been in the format of housing estates in sub-urban areas and as a result the growth of the outskirts of the city. However, they have been followed by strong weaknesses in the required infrastructures. The aim of this research is to introduce the worn out texture of down town of Isfahan as a potential region for future urban development and a cause for preventing the outlines of the city to be widened.

\section{Infill City Development}

Connected development, disconnected development and Infill city development policies are triple urban development polices. Infill city development originally comes back to the formation of first cities, but specifically as a mean to prevent the problems originated from the rapid and unplanned growth of the cities comes back to the late 19th century and then 20th specially after the world war two. A large number of researches form different perspectives have been conducted on this issue, along which practical solutions have been thought of in addition to recognizing the ups and downs of such policy for sustainable urban management. Given the point that the prerequisite for infill city development is presence of citizens and neighborhood units in a city, so this is a complicated and multi-dimensional issue which is not only of physical but also social, cultural, economic and environmental (Dye \& McMillen, 2007; Funderburg \& MacDonald, 2010). Infill city development is based on abandoned lands which are out of use located in the constructed parts of the town with previously planned infrastructures and it is equal to a small scale and high capitation development.

A high percentage of future population growth and housing need in cities can be covered through using abandoned land in down town, having a balanced density, regeneration, renovation and reconstruction of worn out texture and old buildings (Grenadier, 1996; Newell, 2010). Infill city development have the role of neighborhood revitalizer, health and safety risks reducer of worn out textures (Weber et al., 2003; Smith, 2006; Weber et al., 2007; Smith, 2009). United States and Europe were the first ones who applied infill city development policy in 1980 (Cheng et al., 2009) in a way that it is the heart of urban land policies in Europe. Take England for example that had established a rule according to which $60 \%$ of all new houses of this country were recommended to be constructed in worn out texture and previously used lands (Adams \& Watkins, 2002).

\section{Methodology}

Target population of this survey is the residential buildings of the city of Isfahan being one of the future needs of 
this city. The research method in this paper is descriptive-analytical and the data required have been collected both through the library and the field visit. At first, worn out textures were identified and the area they had occupied was measured. Secondly, the number of required houses in the year 2025 was estimated according to the existing number of houses in the city of Isfahan and finally shortage of houses was notified.

\section{The Scope of the Study}

Isfahan is among the most historic cities of Iran with more than 3000 years old located in the center of Iran (Figure 1). In terms of urban division this city is divided into 15 different parts (Figure 2). As the most important industries have been located in Isfahan, a large number of emigrants have been absorbed to this city in the past half century which is in addition to the natural growth of its population as well, in a way that the total population in the year1956 was equal to 287,898 and based on official statistics the population of Isfahan will be $2,563,580$ in the year 2025 .

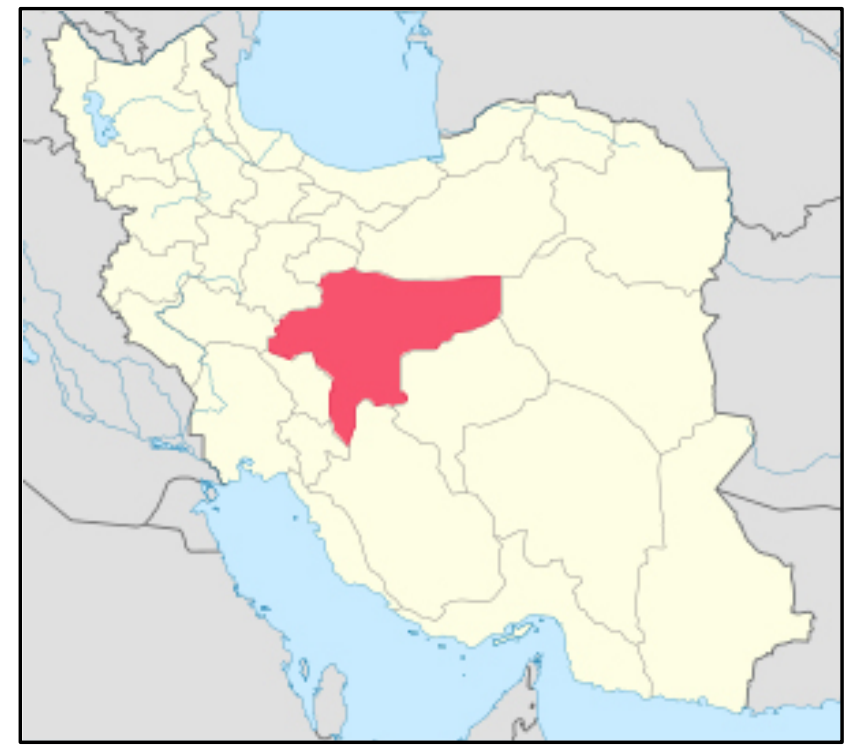

Figure 1. Isfahan in Iran.

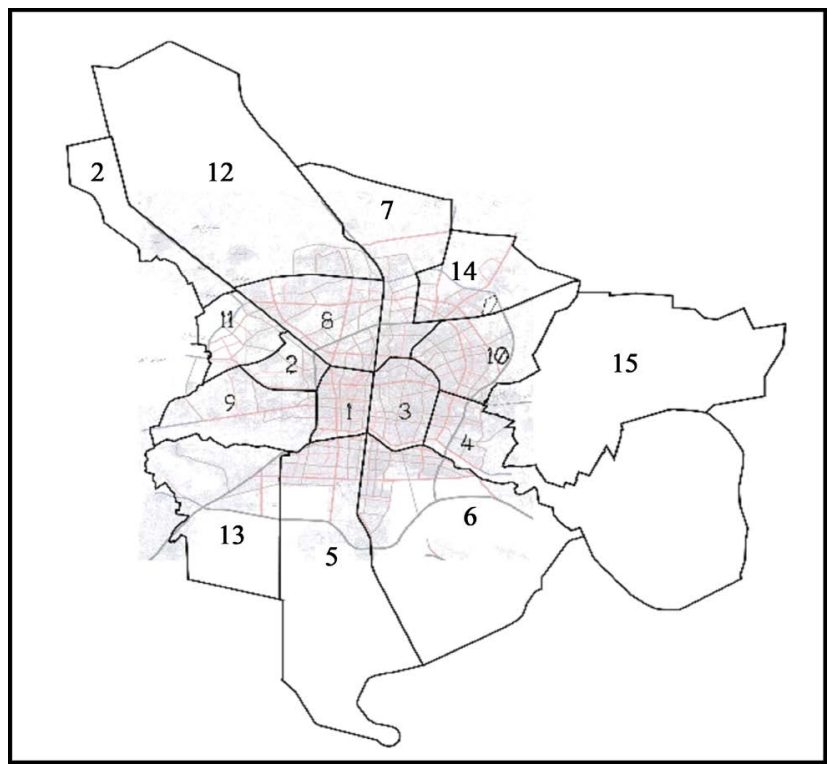

Figure 2. City divide. 
Sudden growth in physical boundaries of the city has resulted in formation of five new suburbs around it in order to accommodate the overflow crowd (Figure 3). Due to the lack of infrastructures in these new suburbs, city managers have faced several major problems. Although formation of these suburbs was costly, they are not still that applicable, just serving as places for sleeping at night. It is in spite of the fact that there are a great part of infrastructures in the inner city fabrics as worn out texture that are out of use because of the lack of good management.

\section{Worn Out Boundaries}

According to the surveys conducted along with the software prepared maps of 15 districts of the city of Isfahan, the overall area of ancient fabrics was estimated to be 2280 Hectares which are spread in different parts of the city. According to the Supreme Council of Architecture in Iran, a worn out texture is a unit which belongs to one of these three groups: 1-Blocks in which more than $50 \%$ of the units have the area of less than $200 \mathrm{~m}^{2} .2$-Blocks that more than $50 \%$ of their parts are unstable, out of structural systems and non-standard. 3-Blocks in which more than $50 \%$ of the pathways are of less than $6 \mathrm{~m}$ weight (Figure 4).

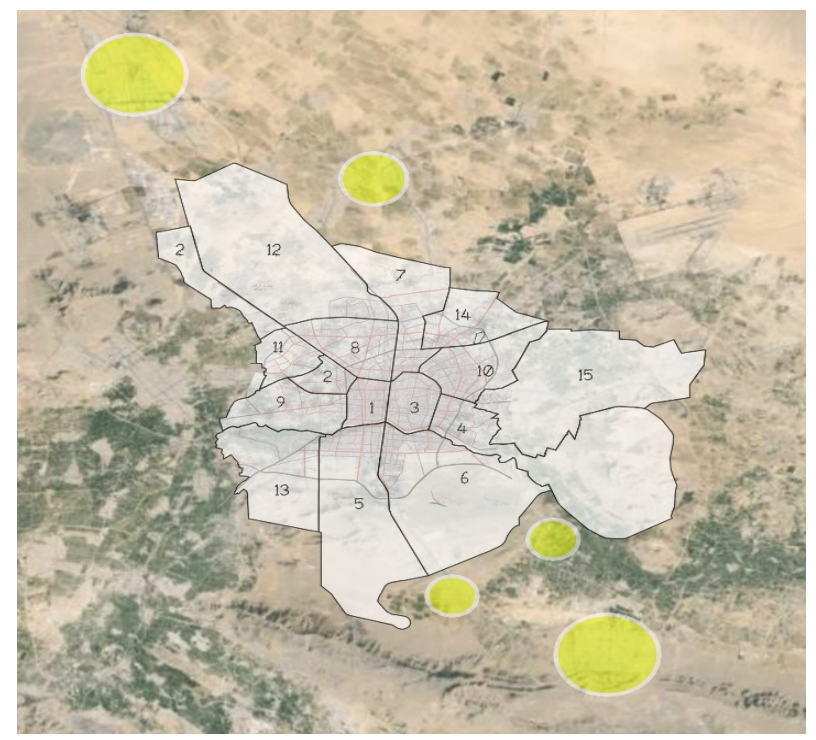

Figure 3. Location of new suburbs around Isfahan.

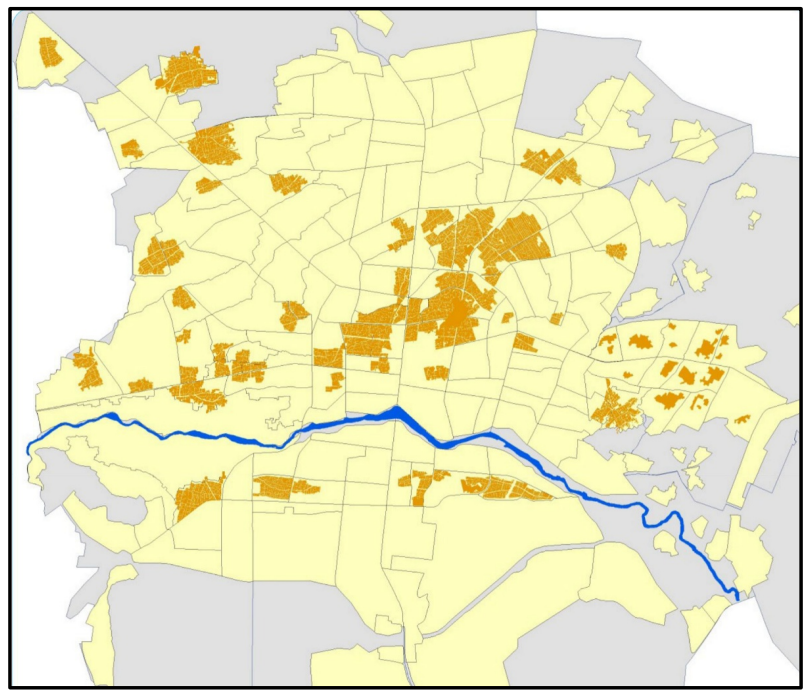

Figure 4. Map of worn out texture of Isfahan. 
Table 1. Number of needed houses in 2025.

\begin{tabular}{|c|c|c|c|c|}
\hline $\begin{array}{c}\text { Population } \\
\text { Estimation (2025) (P) }\end{array}$ & $\begin{array}{c}\text { Average } \\
\text { Household Size (S) }\end{array}$ & $\begin{array}{l}\text { Number of Estimated } \\
\text { Households (2025) (H) }\end{array}$ & $\begin{array}{c}\text { Coefficient of Households } \\
\text { in Housing Units (K) }\end{array}$ & $\begin{array}{c}\text { Number of Needed } \\
\text { Houses (2025) (E) }\end{array}$ \\
\hline $2,563,580$ & 3.1 & 826,961 & 0.99 & 835,042 \\
\hline
\end{tabular}

\section{Estimating Housing Shortage}

In 2015, the population of Isfahan was $1,796,967$ persons and the number of households living in this city is equal to 579,302. Accordingly, the index of housing unit per person is 0.32 and index of housing unit per household is 1. Comparing the number of existing houses in Isfahan in 2015 with the number of households, surprisingly, not only we do not face with the lack of house but with extra 2648 houses.

In this method, estimated population $(P)$ is divided to the average household size $(S)$ in order to have the number of estimated households $(H)$, which is:

$$
H=P / S
$$

In this equation, if the coefficient of households in housing units $(K)$ intervenes, then the number of needed houses $(E)$ can be counted as follows:

$$
E=P / K \times S
$$

The number of needed houses $(E)$ in the year 2025 is estimated to be 835,042 housing units which means that by the year 2025 this number of houses are due to have been built in Isfahan (Table 1). Therefore, with neglecting the extra number of houses in 2015 in Isfahan, 253,092 houses should be built in the next 10 years. In the master plan of Isfahan, residential land use per capita is equal to $27.4\left(\mathrm{~m}^{2}\right)$ per person. Accordingly, residential land use would face a shortage of 2100 hectares in the year 2025 . With regards to the area of 2280 hectares of worn out texture in the down town, the needed houses can be located in the city with the approach of infill city development and according to worn out texture regeneration.

\section{Conclusion}

During the different series of nose counts, the population of Isfahan has faced a rapid increase which is due to the immigrations to this city in different periods of time. The city of Isfahan has been the host of immigrants due to a variety of facilities including political, industrial and administrative, which has resulted in a non-balanced distribution of the population in a way that the authorities have decided to accommodate the overflow population in Isfahan suburbs. This decision has brought about some negative effects among which are the elimination of farms and gardens and some environmental problems. According to this research finding, it can be concluded that in the districts of Isfahan, there are lots of potentials which can be utilized in the best way including the regeneration of worn out texture of this city that can respond to the need of house through revitalization and renovation. According to this research, 2280 hectares of lands in Isfahan are worn out which can obviate the next 10 -year needs of houses. Moreover, inner city development highlights the identity of the city through using abandoned lands. However, it should be noted that it is just one of the infill city development parameters along which the need of future houses can be obviated.

\section{References}

Adams, D., \& Watkins, C. (2002). Greenfield, Brownfield Housing Development European Urban and Regional Research Center. Hoboken: Blackwall Publishing.

Cheng, F., Kuffer, M., Zhan, Q., \& Geertman, S. (2009). Recovering Urban Land: An Integrative Approach to Improve Brownfield Redevelopment Practices: Case of Shenzhen, China. Proceedings of the 11th International Conference on Computers in Urban Planning and Urban Management, Hongkong, 16-18 June 2009.

Cole, R., Bragado, N., Corbett, J., \& Sprowls, S. (1996). New Strategies for Promoting Urban Infill. Urban Land, 55, 37-40

Dye, R. F., \& McMillen, D. P. (2007). Teardowns and Land Values in the Chicago Metropolitan Area. Journal of Urban Economics, 61, 45-63. http://dx.doi.org/10.1016/j.jue.2006.06.003

Funderburg, R., \& MacDonald, H. (2010). Neighborhood Valuation Effects from New Construction of Low-Income Housing Tax Credit Projects in Iowa: A Natural Experiment. Urban Study, 47, 1745-1771. 
http://dx.doi.org/10.1177/0042098009356122

Grenadier, S. R. (1996). The Strategic Exercise of Options: Development Cascades and Over building in Real Estate Markets. The Journal of Finance, 51, 1653-1679. http://dx.doi.org/10.1111/j.1540-6261.1996.tb05221.x

Lang, R. E., Hughes, J. W., \& Danielsen, K. A. (2000). Target Marketing Can Help Attract City Residents. Housing Facts \& Findings, 2, 8-10.

Newell, T. (2010). Development and Neighborhood Revitalization: The Effects of Residential Investment on Property Values in Durham, NV. Michigan Journal of Business, 3, 97-120.

Parizadi, T., Varesi, H., \& Zarabi, A. (2012). Urban Infill Development by Emphasizing Housing (Case Study: Sanandaj City). Journal of Sustainable Development, 5, 112-120. http://dx.doi.org/10.5539/jsd.v5n3p112

Smith, B. C. (2006). The Impact of Tax Increment Financing Districts on Localized Real Estate: Evidence from Chicago's Multifamily Markets. Journal of Housing Economics, 15, 21-37. http://dx.doi.org/10.1016/j.jhe.2006.02.003

Smith, B. C. (2009). If You Promise to Build It, Will They Come? The Interaction between Local Economic Development Policy and the Real Estate Market: Evidence from Tax Increment Finance Districts. Real Estate Economics, 37, $209-234$. http://dx.doi.org/10.1111/j.1540-6229.2009.00240.x

Weber, R., Bhatta, S. D., \& Merriman, D. (2003). Does Tax Increment Financing Raise Industrial Property Values? Urban Study, 40, 2001-2021. http://dx.doi.org/10.1080/0042098032000116086

Weber, R., Bhatta, S. D., \& Merriman, D. (2007). Spillovers from Tax Increment Financing Districts: Implications for Housing Price Appreciation. Regional Science and Urban Economics, 37, 259-281.

http://dx.doi.org/10.1016/j.regsciurbeco.2006.11.003 